\title{
HUBUNGAN KADAR HbA1c DAN KUALITAS TIDUR PADA PASIEN DIABETES MELITUS TIPE 2
}

\author{
Anggri Noorana Zahra, ${ }^{1, *}$, Misella Elvira Farida ${ }^{2}$ \\ ${ }^{1}$ Dosen Departemen Keperawatan Medikal Bedah, \\ Fakultas Ilmu Keperawatan Universitas Indonesia, Depok 16424, Indonesia \\ ${ }^{2}$ Mahasiswa Fakultas Ilmu Keperawatan Universitas Indonesia, Depok 16424, Indonesia \\ *E-mail: anggri.n@ui.ac.id
}

\begin{abstract}
ABSTRAK
Kualitas tidur yang buruk pada pasien diabetes melitus tipe 2 akan berdampak pada kualitas hidupnya. Kualitas tidur yang buruk disebabkan oleh komplikasi diabetes melitus yang diakibatkan oleh status kontrol gula darah yang buruk. Kadar $\mathrm{HbAlc}$ dapat menggambarkan status kontrol gula darah pasien dalam tiga bulan terakhir. Tujuan: Penelitian ini bertujuan untuk mengidentifikasi hubungan kadar HbA1c dengan kualitas tidur pada pasien diabetes melitus tipe 2. Metode: Penelitian ini menggunakan metode cross sectional. Responden adalah pasien diabetes melitus tipe 2 sebanyak 110 orang yang dipilih dengan teknik consecutive sampling. Lokasi penelitian di Poli Endokrin RSUPN Dr. Cipto Mangunkusumo. Data kadar HbA1c diperoleh dari hasil pemeriksaan $\mathrm{HbA1c}$ responden dalam tiga bulan terakhir dan kualitas tidur diukur dengan Pittsburgh Sleep Quality Index (PSQI). Analisis data menggunakan uji deskriptif dan analisis bivariat dengan menggunakan chi square. Hasil penelitian: Hasil penelitian menunjukkan terdapat hubungan yang signifikan antara kadar HbAlc dengan kualitas tidur responden $(\mathrm{p}=0,000)$ dimana responden dengan kadar $\mathrm{HbAlc}$ pada kategori diabetes memiliki peluang 45 kali untuk memiliki kualitas tidur yang buruk dibandingkan responden dengan kadar HbA1c pada kategori normal. Diskusi: Kontrol gula darah yang buruk dapat menyebabkan penderita diabetes menderita neuropati diabetik yang menyebabkan nyeri pada kaki dan osmotik diabetes yang dapat menyebabkan nokturia. Hal tersebut dapat menurunkan kualitas tidur pasien diabetes. Kesimpulan: Penelitian ini merekomendasikan kepada perawat agar memberikan intervensi yang tepat dalam penatalaksanaan diabetes melitus sehingga pasien dapat mempertahankan status kontrol gula darah yang baik dan mendapatkan kualitas tidur yang baik.
\end{abstract}

Kata kunci: diabetes melitus tipe 2, kadar HbA1c, kualitas tidur, Pittsburgh Sleep Quality Index.

\section{The Relationship Between HbA1c Level and Sleep Quality in Patients with Type 2 Diabetes Mellitus}

\section{ABSTRACT}

Poor sleep quality in patients with type 2 diabetes mellitus (T2DM) will have an impact on their quality of life. Poor sleep quality is caused by complications of diabetes mellitus that is caused by poor glycemic control. HbAlc level describes the patient's glycemic control in the last three months. Objective: This study aims to identify the relationship between HbAlc level and sleep quality in patients with T2DM. Methods: The study was using a cross sectional approach, 110 patients with T2DM at the Endocrine Polyclinic of Dr. Cipto Mangunkusumo National General Referal Hospital Jakarta were recruited by consecutive sampling technique. HbAlc level was taken from the results of HbAlc examination of respondents in the last three months and sleep quality was measured by the Pittsburgh Sleep Quality Index (PSQI). The gathered data were analyzed using descriptive and chi-square test. Results: The results of this study indicated that there was a significant correlation between HbA1c level and the sleep quality of respondents $(p=0,000)$. The respondents with HbAlc level in the diabetes category have a 45 times greater chance of experiencing poor sleep quality compared to respondents with levels HbAlc in the normal category. Discussion: Poor blood glycemic control can cause patients to suffer from diabetic neuropathy, which causes pain or uncomfortable sensation in the legs, and osmotic diuresis, which 
can cause nocturia. It can reduce the sleep quality of diabetes patients. Conclusion: This study recommends the nurses to provid education and encourage patients with T2DM to maintain their glycemic control to promote healthy sleep among diabetic.

Keywords: Type 2 diabetes mellitus, HbAlc level, sleep quality, pittsburgh sleep quality index.

\section{LATAR BELAKANG}

Prevalensi Diabetes Melitus (DM) di dunia semakin meningkat. Pada tahun 2015 sebanyak 415 juta orang dewasa menderita DM. Angka ini merupakan kenaikan 4 kali lipat dari 108 juta pada tahun 1980-an. Persentasenya sebanyak $8,5 \%$ sama dengan satu dari sebelas orang dewasa menderita DM. Berdasarkan data International Diabetes Federation (IDF, 2015) penderita DM pada tahun 2040 diperkirakan naik menjadi 642 juta. Prevalensi DM diantara orang dewasa pada tahun 2014 sebanyak 96 juta orang dewasa di wilayah regional Asia Tenggara. Sedangkan di Indonesia berdasarkan data dari Riset Kesehatan Dasar (Riskesdas) tahun 2018, prevalensi DM berdasarkan pemeriksaan gula darah pada penduduk umur $\geq 15$ tahun mengalami peningkatan sebesar $1,6 \%$ dari tahun 2013 sampai tahun 2018, yaitu sebesar $6,9 \%$ pada tahun 2013 dan $8,5 \%$ pada tahun 2018 (Kementerian Kesehatan Republik Indonesia, 2019). Persentase kematian akibat diabetes di Indonesia merupakan yang tertinggi kedua setelah Sri Lanka (IDF, 2015).

Gejala klinis yang timbul pada penderita DM berhubungan dengan status kontrol gula darah yang buruk. Kontrol gula darah pada pasien dapat dievaluasi dengan melihat kadar HbA1c dalam tiga bulan terakhir. Berdasarkan kriteria dari Perkumpulan Endokrinologi Indonesia (Perkeni) tahun 2015 , disebut normal jika hasil pemeriksaan $\mathrm{HbA} 1 \mathrm{c}$ menunjukkan $<5,7 \%$, prediabetes jika HbA1c 5,7-6,4\%, dan diabetes jika $\mathrm{HbA} 1 \mathrm{c} \geq 6,5 \%$.
Kadar gula darah yang tinggi pada pasien DM tipe 2 menimbulkan tanda dan gejala yang sering muncul yaitu nafsu makan meningkat, rasa haus yang berlebihan, seringnya keinginan untuk buang air kecil terutama pada malam hari, penurunan berat badan, dan kelelahan. Penatalaksanaan yang tidak baik akan menyebabkan berkembangnya gejala-gejala tersebut menjadi komplikasi seperti neuropati (Grossman \& Porth, 2014). Gejala klinis dan komplikasi tersebut akan memengaruhi kualitas tidur pada pasien DM. Penelitian oleh Surani, dkk (2015) pada pasien DM tipe 2 menunjukkan bahwa kondisi yang dapat memengaruhi kualitas maupun kuantitas tidur pada pasien DM meliputi nokturia, poliuria, noktural hipoglikemia, neuropati diabetik, obstruktif sleep apnea, restless leg syndrome, komplikasi kardiovaskular, hipertensi, stroke dan depresi.

Kualitas tidur merupakan gambaran subjektif mengenai kemampuannya untuk mempertahankan waktu tidur dan tidak adanya gangguan tidur. Semua pasien membutuhkan tidur yang berkualitas sehingga tubuh mereka dapat memperoleh kembali energi dan daya tahan tubuh (Delaune \& Ladner, 2011).

Penurunan kualitas tidur dapat menurunkan sistem kekebalan tubuh (Delaune \& Ladner, 2011). Sebuah survei yang dilakukan di Belanda tahun 2015 dengan subyek orang dewasa muda usia 18-35 tahun sebanyak 574 orang menunjukkan bahwa sebanyak $36,4 \%$ responden memiliki skor SLEEP tinggi yang menggambarkan kualitas tidur yang buruk dan melaporkan 
adanya penurunan kekebalan tubuh (Donners, dkk, 2015). Selain itu, penurunan kualitas tidur pada individu juga dapat merusak kemampuan pasien untuk berpikir dengan jernih, kelelahan fisik, kemampuan merespon dengan cepat dan produktivitas kerja menurun. Hal tersebut akan memengaruhi kemampuan pasien dalam pengelolaan manajemen DM secara mandiri terkait dengan status metabolik yang bertujuan untuk mempertahankan kadar glukosa darah dalam batas normal serta mencegah terjadinya hipoglikemi dan hiperglikemi (Delaune \& Ladner, 2011).

Beberapa penelitian di Indonesia menunjukkan adanya hubungan antara kadar gula darah dengan gangguan tidur. Penelitian yang dilakukan oleh Tentero, dkk (2016) menunjukkan terdapat hubungan yang signifikan antara kadar gula darah puasa dengan gangguan tidur. Penelitian lain menunjukkan adanya hubungan yang signifikan antara skor insomnia dengan kadar gula darah 2 jam post prandial (Wahyuningsih, Huriah, \& Sari, 2016). Penelitian di Puskesmas Cimanggis Depok menunjukkan bahwa sebagian besar pasien DM tipe 2 memiliki skor PSQI> 5, yang menggambarkan bahwa responden memiliki kualitas tidur yang buruk yaitu sebanyak 63,2\% (Aini, 2016). Kondisi tersebut dapat berhubungan dengan ketidakstabilan kontrol kadar gula darah. Kontrol gula darah pada pasien secara akurat dapat dievaluasi dengan melihat kadar $\mathrm{HbA} 1 \mathrm{c}$ dalam tiga bulan terakhir.

Pada penelitian ini, kualitas tidur diukur dengan PSQI (Pittsburgh Sleep quality Index) untuk menganalisis kualitas tidur selama satu bulan dan data kadar gula darah dikumpulkan dengan pengukuran HbA1c yang terstandarisasi oleh National Glycohaemoglobin standarization Program (NGSP). Penelitian ini dilakukan di poli penyakit dalam khususnya poli endokrin
RSUPN Dr. Cipto Mangunkusumo. Jumlah pasien DM tipe 2 di poli endokrin RSCM dari periode Agustus sampai Oktober 2018 berjumlah 200 orang. Studi pendahuluan yang dilakukan pada bulan Oktober 2018 pada 10 orang pasien DM tipe 2 didapatkan hampir semuanya mengeluhkan sering mengalami gangguan tidur dan 7 diantaranya memiliki status kontrol gula darah yang buruk $(\geq 6,5 \%)$.

Mereka mengeluhkan sering terbangun di malam hari untuk berkemih dan sulit untuk memulai tidur kembali, merasa haus, atau merasa badannya lemas dan rasa tidak nyaman pada kaki. Berdasarkan fenomena tersebut maka peneliti tertarik untuk meneliti apakah ada hubungan antara kadar HbA1c dengan kualitas tidur pada pasien DM tipe 2.

\section{METODE}

Penelitian ini menggunakan desain analisis korelatif dengan pendekatan cross sectional. Penelitian melibatkan 110 responden yaitu pasien dengan diabetes melitus tipe 2 yang berusia 30-60 tahun dan mempunyai data hasil laboratorium kadar HbA1c dalam 1-3 bulan terakhir di poli endokrin RSCM yang dipilih dengan teknik consecutive sampling.

Instrumen yang digunakan pada penelitian ini adalah Pittsburgh Sleep Quality Index (PSQI) yang telah diterjemahkan ke dalam Bahasa Indonesia untuk menganalisis kualitas tidur selama satu bulan. Instrumen asli dikembangkan oleh Buysse, dkk (2008) di Universitas Pittsburgh Amerika, dengan nilai Cronbach's alpha 0,902. Hasil uji validitas PSQI dalam Bahasa Indonesia didapatkan nilai validitas berkisar antara 0,394-0,632 (>0,361) dan nilai reliabilitas 0,469 yang menujukkan instrumen ini valid dan reliabel (Indrarini \& Zahra, 2018). PSQI mengukur kualitas tidur yang terdiri dari tujuh komponen, yaitu kualitas tidur subjektif, latensi tidur, durasi tidur, 
gangguan tidur, efisiensi tidur, penggunaan obat tidur, dan disfungsi tidur pada siang hari. Penilaian terhadap hasil dari jawaban kuesioner memiliki rentang 0-3, selanjutnya dijumlahkan dari masing-masing komponen sampai didapatkan jumlah total 0-21. Interprestasi data kualitas tidur baik jika skor $\leq 5$ dan buruk jika skor $>5$.

Uji validitas dan reliabilitas pada penelitian ini dilakukan terhadap 28 orang responden di Poli Endokrin RSCM di luar responden penelitian. Hasil uji validitas yang telah dilakukan peneliti pada setiap komponen kuesioner didapatkan 3 pertanyaan yang tidak valid $(r<0,374)$ dari 18 pertanyaan dengan nilai reliabilitas 0,902 . Sebagai pertimbangan bahwa item pertanyaan yang tidak valid tersebut merupakan satu kesatuan dari instrumen untuk menilai kualitas tidur maka peneliti tidak membuang item pertanyaan tersebut dan hanya mengubah redaksional kalimat sehingga tidak merubah sistem skor penilaian yang sudah valid.

Kadar gula darah dalam penelitian ini dikumpulkan dengan melihat hasil pengukuran $\mathrm{HbA} 1 \mathrm{C}$ dari rekam medik pasien dalam kurun waktu 1-3 bulan terakhir. Kadar HbA1c sesuai dengan kadar gula darah pada pasien DM tipe 2 selama masa hidup sel darah merah yaitu 120 hari. Hasil pemeriksaan $\mathrm{HbA} 1 \mathrm{C}$ dinyatakan dalam 3 kategori, yaitu normal $(<5,7 \%)$, prediabetes $(5,7 \%-6,4 \%)$, dan diabetes $(\geq 6,5 \%)$ (Perkeni, 2015).

Analisis data yang digunakan dalam penelitian ini adalah analisis univariat dan bivariat. Analisis univariat menggambarkan karakteristik responden, kadar $\mathrm{HbA} 1 \mathrm{c}$, dan kualitas tidur responden. Analisis bivariat pada penelitian ini menggunakan chi square untuk menganalisis hubungan antara kadar HbA1c dengan kualitas tidur responden. Persetujuan lulus etik dari komite etik FK UI-RSCM diperoleh sebelum penelitian dilakukan.

\section{HASIL}

Karakteristik responden ditampilkan pada Tabel 1. Hasil penelitian menunjukkan bahwa lebih dari setengah responden adalah perempuan $(63,6 \%)$, berada dalam kategori lansia awal $(68,2 \%)$, memiliki pendidikan SMP- SMA $(61,8 \%)$, dan tidak bekerja $(59,1 \%)$. Rata-rata usia responden adalah 51,58 tahun dengan usia paling muda 39 tahun dan paling tua 59 tahun. Lebih lanjut, lebih dari setengah responden mempunyai kadar $\mathrm{HbA} 1 \mathrm{c}$ yang masuk kategori diabetes $(60 \%)$ dan mengalami kualitas tidur yang masuk kategori buruk (60\%).

Tabel 2 menunjukkan hubungan karakteristik dengan kualitas tidur. Kualitas tidur yang buruk cenderung lebih banyak dialami responden laki-laki (65\%). Kualitas tidur responden berdasarkan usia yaitu kualitas tidur buruk lebih banyak dialami oleh lansia akhir $(66,7 \%)$. Semakin bertambah usia, maka semakin tinggi potensi untuk memiliki kulitas tidur yang buruk. Kualitas tidur berdasarkan pendidikan bahwa kualitas tidur yang buruk paling banyak dialami oleh responden dengan pendidikan terakhir SD (75\%). Dari hasil analisis didapatkan bahwa semakin rendah pendidikan semakin tinggi persentase yang mengalami kualitas tidur buruk. Kualitas tidur responden yang buruk sebagian besar dialami oleh kelompok tidak bekerja $(63,1 \%)$. Berdasarkan hasil uji chi square didapatkan bahwa tidak ada hubungan antara karakteristik responden dengan kualitas tidur.

Keluhan gangguan tidur yang sering dialami (lebih dari $3 x$ setiap minggu) oleh responden dalam satu bulan terakhir paling banyak yaitu harus bangun untuk ke kamar mandi $(59,1 \%)$, tidak bisa tidur dalam waktu 30 menit $(57,3 \%)$, dan merasa nyeri $(49,1 \%)$ (Tabel 3).

Tabel 4 menunjukkan hubungan kadar $\mathrm{HbA} 1 \mathrm{c}$ dengan kualitas tidur. Hasil analisis chi square menunjukkan bahwa terdapat 
hubungan yang signifikan antara kadar $\mathrm{HbA1c}$ dengan kualitas tidur responden $(p=0,000)$ dengan $\mathrm{OR}=6,042(95 \% \mathrm{Cl}$ : $1,242-29,378)$, yang artinya responden dengan kadar $\mathrm{HbA} 1 \mathrm{c}$ pada kategori prediabetes mempunyai peluang 6 kali lebih besar untuk memiliki kualitas tidur yang buruk dibandingkan dengan responden pada kategori normal. Sedangkan pada kategori diabetes dibandingkan dengan kategori normal didapatkan OR=45,917 (95\% Cl:13,027-161,840), yang artinya responden dengan kadar $\mathrm{HbA} 1 \mathrm{c}$ pada kategori diabetes memiliki peluang 45,9 kali lebih tinggi untuk memiliki kualitas tidur yang buruk dibandingkan responden dengan kadar $\mathrm{HbA} 1 \mathrm{c}$ pada kategori normal.

Tabel 1. Distribusi Responden Berdasarkan Karakteristik Demografi, Kadar HbA1c dan Kualitas Tidur $(n=110)$

\begin{tabular}{lll}
\multicolumn{1}{c}{ Variabel } & Frekuensi (n) & Persentase (\%) \\
Jenis Kelamin & & \\
\hline Laki- laki & 40 & 36,4 \\
\hline Perempuan & 70 & 63,6 \\
\hline Usia & 11 & 10,0 \\
\hline Dewasa akhir (35-45) & 75 & 68,2 \\
\hline Lansia awal (46-55) & 24 & 21,8 \\
\hline Lansia akhir (56-65) & & \\
\hline Pendidikan & 20 & 18,2 \\
\hline SD & 68 & 61,8 \\
\hline SMP-SMA & 22 & 20,0 \\
\hline PT & & \\
\hline Pekerjaan & 45 & 40,9 \\
\hline Bekerja & 65 & 59,1 \\
\hline Tidak Bekerja & & \\
\hline Kadar HbA1c & 33 & 30 \\
\hline Normal & 11 & 10 \\
\hline Prediabetes & 66 & 60 \\
\hline Diabetes & 44 & 40 \\
\hline Kualitas Tidur & 66 & \\
\hline Baik & & \\
\hline Buruk & & \\
\hline
\end{tabular}


Tabel 2. Hubungan Karakteristik dengan Kualitas Tidur $(n=110)$

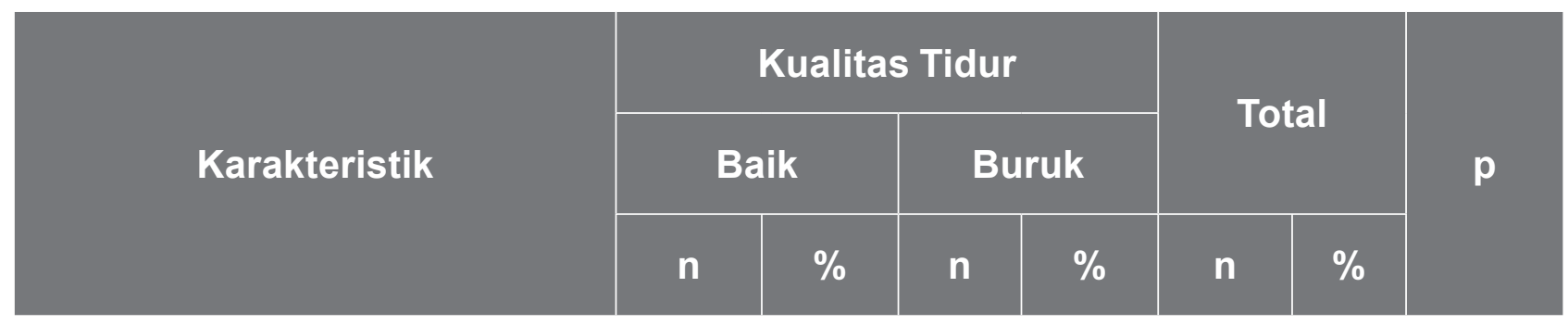

Jenis Kelamin

\begin{tabular}{llllllll}
\hline Laki- laki & 14 & 35 & 26 & 65 & 40 & 100 & 0,544 \\
\cline { 1 - 5 } Perempuan & 30 & 42,9 & 40 & 57,1 & 70 & 100 \\
\hline
\end{tabular}

Usia

\begin{tabular}{lllllll}
\hline Dewasa akhir & 5 & 45,5 & 6 & 54,5 & 11 & 100 \\
\hline Lansia awal & 31 & 41,3 & 44 & 58,7 & 75 & 100 \\
\hline Lansia akhir & 8 & 33,3 & 16 & 66,7 & 24 & 100 \\
\hline
\end{tabular}

Pendidikan

\begin{tabular}{lllllll}
\hline SD & 5 & 25 & 15 & 75 & 20 & 100 \\
\hline SMP-SMA & 29 & 42,6 & 39 & 57,4 & 68 & 100 \\
\hline PT & 10 & 45,5 & 10 & 54,5 & 22 & 100 \\
\hline
\end{tabular}

\section{Pekerjaan}

\begin{tabular}{llllllll}
\hline Bekerja & 20 & 44,4 & 25 & 55,6 & 45 & 100 & 0,553 \\
\cline { 1 - 5 } Tidak Bekerja & 24 & 36,9 & 41 & 63,1 & 65 & 100 \\
\hline
\end{tabular}


Tabel 3. Keluhan Gangguan Tidur $(n=110)$

\begin{tabular}{|c|c|c|c|c|c|c|c|c|}
\hline \multirow[t]{2}{*}{$\begin{array}{l}\text { Gangguan tidur } \\
\text { (dalam sebulan) }\end{array}$} & \multicolumn{2}{|c|}{$\begin{array}{c}\text { Tidak } \\
\text { pernah }\end{array}$} & \multicolumn{2}{|c|}{$\begin{array}{c}1 \mathrm{x} \\
\text { seminggu }\end{array}$} & \multicolumn{2}{|c|}{$\begin{array}{c}2 \mathrm{x} \\
\text { seminggu }\end{array}$} & \multicolumn{2}{|c|}{$\begin{array}{l}\text { Lebih dari } \\
3 x \text { setiap } \\
\text { minggu }\end{array}$} \\
\hline & $\mathbf{n}$ & $\%$ & $\mathbf{n}$ & $\%$ & $\mathbf{n}$ & $\%$ & $\mathbf{n}$ & $\%$ \\
\hline
\end{tabular}

Tidak bisa tidur dalam waktu 30 menit

$12 \quad 10,9 \quad 19 \quad 17,3 \quad 16 \quad 14,5 \quad 63 \quad 57,3$

Bangun di tengah malam atau terlalu pagi

$\begin{array}{llllllll}28 & 25,5 & 11 & 10 & 20 & 18,2 & 51 & 46,4\end{array}$

Harus bangun untuk ke kamar

\begin{tabular}{lllllllll} 
mandi & 7 & 6,4 & 12 & 10,9 & 26 & 23,6 & 65 & 59,1 \\
\hline $\begin{array}{l}\text { Tidak dapat bernafas dengan } \\
\text { nyaman }\end{array}$ & 39 & 35,5 & 32 & 29,1 & 20 & 18,2 & 19 & 17,3 \\
\hline Batuk di malam hari & 47 & 42,7 & 28 & 25,5 & 8 & 7,3 & 27 & 24,5 \\
\hline Merasa kedinginan pada saat tidur & 86 & 78,2 & 4 & 3,6 & 4 & 3,6 & 16 & 14,5 \\
\hline Merasa kepanasan pada saat tidur & 47 & 42,7 & 32 & 29,1 & 16 & 14,5 & 15 & 13,6 \\
\hline Mimpi buruk & 59 & 53,6 & 0 & 0 & 3 & 2,7 & 48 & 43,6 \\
\hline Merasa nyeri & 18 & 16,4 & 14 & 12,7 & 24 & 21,8 & 54 & 49,1 \\
\hline
\end{tabular}

Tabel 4. Hubungan Kadar HbA1c dengan Kualitas Tidur $(n=110)$

\begin{tabular}{|c|c|c|c|c|c|c|c|c|}
\hline \multirow{3}{*}{ Kadar HbA1C } & \multicolumn{4}{|c|}{ Kualitas Tidur } & \multirow{2}{*}{\multicolumn{2}{|c|}{ Total }} & \multirow{3}{*}{ OR $(95 \% \mathrm{Cl})$} & \multirow{3}{*}{$p$} \\
\hline & \multicolumn{2}{|c|}{ Baik } & \multicolumn{2}{|c|}{ Buruk } & & & & \\
\hline & $\mathrm{n}$ & $\%$ & $\mathrm{n}$ & $\%$ & $\mathrm{n}$ & $\%$ & & \\
\hline Normal & 29 & 87,9 & 4 & 12,1 & 33 & 30 & Pembanding & \\
\hline Prediabetes & 6 & 54,5 & 5 & 45,5 & 11 & 10 & $6,042(1,242-29,378)$ & \\
\hline Diabetes & 9 & 13,6 & 57 & 86,4 & 66 & 60 & $\begin{array}{l}45,917(13,027- \\
161,840)\end{array}$ & \\
\hline
\end{tabular}




\section{DISKUSI}

Hasil penelitian ini menunjukkan bahwa kadar $\mathrm{HbA} 1 \mathrm{c}$ responden dalam 2 sampai 3 bulan terakhir lebih dari setengahnya berada pada kategori diabetes $(\geq 6,5 \%)$ yaitu sebanyak 66 orang $(60 \%)$. Kondisi ini menunjukkan bahwa dalam penelitian ini status kontrol gula darah pada pasien DM tipe 2 termasuk kategori buruk (Perkeni, 2015). Penelitian yang sejalan yaitu penelitian oleh Prasetyani (2015) di Jawa Tengah yang menunjukkan bahwa rata-rata kontrol gula darah yang didapatkan dari hasil pemeriksaan $\mathrm{HbA} 1 \mathrm{c}$ pada pasien DM tipe 2 yaitu $8,02 \%$ dengan kadar $\mathrm{HbA} 1 \mathrm{c}$ terendah $6 \%$ dan tertinggi $11 \%$. Penelitian lain di Jordania pada responden dengan DM tipe 2 didapatkan sebanyak $70 \%$ responden memiliki kadar $\mathrm{HbA} 1 \mathrm{c}$ dalam kategori tidak terkontrol ( $\geq 7 \%$ ) (Barakat, dkk, 2019). Dalam penelitian ini beberapa responden menunjukkan status kontrol gula darah yang baik, yaitu responden yang berada pada kategori normal sebanyak 33 orang $(30 \%)$ dan prediabetes sebanyak 11 orang (10\%).

HbA1c adalah salah satu fraksi hemoglobin dalam tubuh yang berikatan dengan glukosa secara enzimatik. Kadar HbA1c sesuai dengan kadar gula darah pada pasien DM tipe 2 selama masa hidup sel darah merah yaitu 120 hari (Hinzmann, Schlaeger \& Tran, 2012). Pemeriksaan $\mathrm{HbA} 1 \mathrm{c}$ harus menggunakan metode HighPerformance Liquid Chromotography (HPLC) yang terstandarisasi oleh National Glycohaemoglobin standarization Program (NGSP). Pemeriksaan HbA1c lebih dianjurkan untuk menegakkan diagnosis diabetes, karena berdasarkan National Health and Nutrition Examination Survey (NHANES), kadar HbA1c dapat mengidentifikasi kasus diabetes yang tak terdiagnosis sepertiga lebih banyak dibandingkan pemeriksaan kadar gula darah puasa (American Diabetes Association
[ADA], 2018).

Hasil pemeriksaan kadar $\mathrm{HbA} 1 \mathrm{c}$ mencerminkan kadar glukosa pada 3 bulan sebelumnya. Melalui pemeriksaan ini, dapat diketahui kemampuan pasien DM tipe 2 dalam mengontrol gula darahnya dan juga memprediksi kemungkinan terjadinya komplikasi atau perbaikan. Kadar HbA1c menunjukkan kontrol gula darah jangka panjang lebih baik daripada kadar gula darah atau urin yang bersifat jangka pendek dalam hitungan hari atau jam (Sack, dkk, 2011).

Faktor-faktor yang menjadi penyebab kontrol gula darah buruk pada pasien DM tipe 2 adalah pengetahuan tentang diabetes dan penatalaksanaannya. Rata-rata $\mathrm{HbA} 1 \mathrm{c}$ pasien DM tipe 2 dengan pengetahuan kurang adalah 0,935\% lebih tinggi dibandingkan pasien DM dengan pengetahuan baik (Prasetyani, 2015). Pengetahuan merupakan domain yang penting untuk membentuk perilaku individu, perilaku yang didasari oleh pengetahun lebih langgeng karena didasari oleh kesadaran diri bukan paksaan dari luar (Notoatmodjo, 2010). Sehingga pengetahuan individu tentang penyakit DM dan penatalaksanaannya dapat mempengaruhi perilaku individu untuk mengurangi ancaman dari penyakit DM.

Faktor lain yang mempengaruhi kontrol gula darah adalah penggunaan obat hipoglikemia. Penelitian Prasetyani (2015), menunjukkan bahwa perbedaan penggunaan terapi berpengaruh pada kadar HbA1c. Rata- rata kontrol gula darah atau HbA1c terendah adalah pada pasien yang menggunakan terapi kombinasi oral dan insulin dibandingkan pada pasien yang menggunakan terapi oral saja atau terapi insulin saja. Hal tersebut disebabkan oleh efektifitas obat, dimana selain menggunakan obat oral pasien juga menggunakan injeksi insulin untuk menurunkan kadar gula darahnya.

Hasil penelitian ini menunjukkan bahwa 
terdapat hubungan yang signifikan antara kadar $\mathrm{HbA1 \textrm {c }}$ dengan kualitas tidur pada pasien DM tipe 2. Responden dengan kadar HbA1c pada kategori prediabetes mempunyai peluang 6 kali untuk memiliki kualitas tidur buruk. Sedangkan responden dengan kadar HbA1c pada kategori diabetes memiliki peluang 45,9 kali untuk memiliki kualitas tidur yang buruk. Hal ini sejalan dengan penelitian di Manado pada 78 pasien DM tipe 2 dengan mengukur kadar gula darah puasa responden dan gangguan tidur dengan Insomnia Rating Scale, didapatkan bahwa paling banyak responden memiliki kadar gula darah puasa $>110 \mathrm{mg} / \mathrm{dL}$ sebanyak $74,4 \%$ dan 46 responden dengan persentasi $59 \%$ mengalami gangguan tidur. Hasil analisis bivariat menunjukkan bahwa terdapat hubungan yang signifikan antara kadar gula darah puasa dengan gangguan tidur (Tentero, dkk, 2016).

Penelitian yang dilakukan di Taiwan tahun 2013 pada responden prediabetes dan diabetes menunjukkan bahwa subjek dengan kadar gula darah pada kategori diabetes yang baru terdiagnosis lebih banyak memiliki skor PSQI (Pittsburgh Sleep quality Index) tinggi yaitu sebanyak $68,9 \%$ dibanding dengan subjek yang memiliki toleransi glukosa normal yaitu sebanyak $50,3 \%$. Hasil uji Anova menunjukkan bahwa terdapat perbedaan rata-rata skor PSQI pada responden dengan kategori toleransi glukosa NGT (Normal glucose tolerance), IFG (Impaired fasting glucose), IGT (Impaired glucose tolerance), IFG+IGT, dan NDD (Newly diagnosed diabetes), dimana semakin tinggi nilai glukosa darah diikuti dengan semakin tingginya skor PSQ। (Hung, dkk., 2013). Penelitian selanjutnya di Jordania menunjukkan bahwa terdapat hubungan antara kadar $\mathrm{HbA} 1 \mathrm{c}$ dengan kualitas tidur dengan nilai $p=0,000$. Pada responden dengan kadar $\mathrm{HbA} 1 \mathrm{c}$ pada kategori tidak terkontrol $(\geq 7)$ terdapat
$85,7 \%$ yang memiliki kualitas tidur yang buruk, sedangkan pada responden dengan kadar $\mathrm{HbA} 1 \mathrm{c}$ terkontrol $(<7)$ terdapat $70 \%$ responden dengan kualitas tidur yang buruk (Barakat, dkk., 2019).

Kontrol gula darah yang buruk dapat menyebabkan penderita diabetes menderita neuropati diabetik yang menyebabkan nyeri ada kaki dan osmotik diabetes yang dapat menyebabkan nokturia sehingga sering ke kamar mandi pada malam hari untuk buang air kecil (Barakat, dkk., 2019). Hal tersebut sejalan dengan yang diungkapkan oleh Surani, dkk (2015) bahwa kondisi yang dapat memperburuk kualitas tidur pada pasien diabetes diantaranya adalah nokturia dan Restless Legs Syndrome (RLS).

Hasil penelitian ini menunjukkan responden yang mengalami gangguan tidur karena harus ke kamar mandi lebih dari tiga kali dalam seminggu sebanyak $59,1 \%$. Hal ini sejalan dengan penelitian yang dilakukan oleh Chang, dkk (2017), yang didapatkan hasil terdapat hubungan yang signifikan antara nokturia dengan kualitas tidur $(p<$ $0,001)$. Kadar glukosa darah yang meningkat dan tersaring melebihi kemampuan sel tubulus ginjal untuk melakukan reabsorpsi maka glukosa akan muncul dalam urin (glukosuria). Glukosa dalam urin dapat meningkatkan osmolaritas cairan tubulus sehingga menyebabkan diuresis osmotik yang merupakan kondisi terjadinya penambahan cairan ke filter urin agar hasil urin tidak terlalu pekat (akibat glukosa). Hal ini terjadi karena air mengikuti glukosa secara osmosis. Keadaan ini menyebabkan kondisi sering berkemih atau poliuri (Sherwood, 2012).

Hasil dari reduksi glukosa adalah sorbitol yang akan diubah menjadi fruktosa. Kondisi kadar gula darah yang tinggi akan menyebabkan penimbunan fruktosa dan sorbitol yang menyebabkan perubahan biokimia pada jaringan syaraf sehingga 
dapat mengganggu proses metabolik dan hilangnya akson (Price \& Wilson, 2012). Hal tersebut menyebabkan menurunnya fungsi sensori dan motoris yang membuat munculnya nyeri syaraf seperti mati rasa, menusuk, kesemutan atau sensasi terbakar yang membuat penderita DM terjaga pada malam hari. Rasa nyeri pada penderita diabetes akan dirasakan pada bagian ektremitas bawah (Smeltzer \& Bare, 2012). Penelitian di Brazil membuktikan bahwa terdapat hubungan yang signifikan antara Restless Leg Syndrome (RLS) dengan kualitas tidur pada pasien DM tipe 2 dengan nilai $p=0,04$ (Lopes, dkk., 2015). Pada penelitian ini responden yang mengalami gangguan tidur akibat nyeri pada kaki lebih dari tiga kali dalam seminggu yaitu sebanyak $49,1 \%$.

Penelitian ini memberikan implikasi pada pelayanan untuk memberikan informasi bahwa sebagian besar responden masih memiliki status kontrol gula darah yang buruk dan berpengaruh pada kualitas tidur responden. Hal ini juga dapat menjadi sumber informasi bagi ilmu keperawatan bahwa dengan kadar $\mathrm{HbA} 1 \mathrm{c}$ yang tidak terkontrol dapat menjadi salah satu faktor penyebab kualitas tidur buruk pada pasien DM tipe 2.

\section{SIMPULAN}

Hasil penelitian ini menunjukkan bahwa sebagian besar responden memiliki kadar $\mathrm{HbA} 1 \mathrm{c}$ yang belum terkontrol dengan baik dan terdapat hubungan yang signifikan antara kadar $\mathrm{HbA} 1 \mathrm{c}$ dengan kualitas tidur pada pasien DM tipe 2, dimana pasien dengan kadar $\mathrm{HbA} 1 \mathrm{c}$ pada kategori diabetes memiliki peluang 45 kali untuk memiliki kualitas tidur buruk dibandingkan psien dengan $\mathrm{HbA} 1 \mathrm{c}$ normal. Oleh karena itu, peneliti merekomendasikan kepada pelayanan untuk memberikan fasilitas edukasi secara khusus yang dilakukan oleh perawat kepada pasien DM untuk edukasi penatalaksanaan diabetes secara mandiri dan memantau status kontrol gula darah sehingga pelayanan tersebut terintegrasi dengan pelayanan medis.

\section{DAFTAR PUSTAKA}

Aini, A. (2016). Faktor- faktor yang berhubungan dengan kualitas tidur pada pasien diabetes melitus di Puskesmas Cimanggis Depok (Skripsi). FIK UI, Depok, Indonesia.

American Diabetes Association. (2018). Standards ofm medical care in diabetes. Retrieved from http://www. diabetes.org/diabetesccare.

Barakat, S., Abujbara, M., Banimustafa, R., Batieha, A., \& Ajlouni, K. (2019). Sleep quality in patients with type 2 diabetes mellitus. Journal of Clinical Medicine Research, 11(4): 261-266. https://doi.org/10.14740/ jocmr2947w

Buysse, D. J., Hall, M. L., Strolo, P. J, Kamarck, T, W., Owens, J. \& Lee, L. (2008). Relationships between the Pittsburgh sleep quality index, Epworth sleepiness scale, and clinical/Polysomnographic measures in a community sample. Journal of clinical Sleep Medicine, 4(6): 563-571.

Chang, C. J., Pei, D., Wu, C. C., Palmer, M. H., Su, C. C., Kuo, S. F., \& Liao, Y. M. (2017). Correlates of nocturia and relationships of nocturia with sleep quality and glycemic control in women with type 2 diabetes. Journal of Nursing Scholarship, 49(4): 400-410. https://doi.org/10.1111/ jnu.12302

DeLaune, C. S., \& Ladner, K. P. (2011). Fundamental nursing: standars \& practice. 4th edition. USA: Delmar Cengange Learning.

Donners, A. A. M. T., Tromp, M. D. P., Garssen, J., Roth, T., \& Verster, 
J. C.(2015). Perceived immune status and sleep: A survey among Dutch Students. Sleep Disorders: 1-5. https://doi. org/10.1155/2015/721607

Grossman, S. \& Porth, C. M. (2014). Porth's pathophysiologi. 9th Edition. Philadelpia: Wolter Kluwer Health.

Hinzmann, R.., Schlaeger, C., \& Tran T. (2012). What do we need beyond hemoglobin $\mathrm{A} 1 \mathrm{c}$ to get the complete picture of glycemia in people with diabetes. International Journal of Medical Sciene, 9: 665-681.

Hung, H. C., Yang, Y. C., Ou, H. Y., Wu, J. S., Lu, F. H., \& Chang, C. J. (2013). The relationship between impaired fasting glucose and self-reported sleep quality in a Chinese population. Clinical Endocrinology, 78(4): 518-524. https://doi.org/10.1111/j.13652265.2012.04423.x

Indrarini, A., Zahra, A. N. (2018). Hubungan Anemia Dan Depresi Dengan Kualitas Tidur Pasien Penyakit Ginjal Tahap Akhir (Pgta) (Skripsi). FIK UI, Depok, Indonesia.

International Diabetes Federation. (2015). IDF diabetes atlas. Retrieved from https://www.idf.org/e-library/ epidemiology-research/diabetesatlas/13-diabetes-atlas-seventhedition.html

Kementerian Kesehatan Republik Indonesia. (2019). Hasil utama Riskesdas 2018. Retrieved from http://www. kesmas.kemkes.go.id/assets/ upload/dir_519d41d8cd98f00/files/ Hasil-riskesdas-2018 1274.pdf

Lopes, L. A., Lins, C. D. M. M., Adeodato, V. G., Quental, D. P., De Bruin, P. F. C., Montenegro, R. M., \& De Bruin, V. M. S. (2005). Restless legs syndrome and quality of sleep in type 2 diabetes. Diabetes Care, 28(11): 2633-2636. https://doi. org/10.2337/diacare.28.11.2633.

Notoatmodjo, S. (2010). IImu perilaku kesehatan. Jakarta: Rika Cipta.

Perkumpulan Endokrinologi Indonesia. (2015). Konsesus pengelolaan dan pencegahan diabetes melitus tipe 2 di Indonesia. Retrieved from https://pbperkeni.or.id/wp-content/ uploads/2019/01/4.-KonsensusPengelolaan-dan-PencegahanDiabetes-melitus-tipe-2-diIndonesia-PERKENI-2015.pdf.

Prasetiyani, D. (2015). Hubungan diabetes patient empowerment dengan kontrol gula darah psda pasien diabetes melitus tipe 2 (Skripsi). FIK UI, Depok, Indonesia.

Price, S. A., \& Wilson, L. M. (2012). Pathophysiology: clinical concepts of disease process. Mosby: Elsevier Science.

Sack, D. B., Arnold, M., Bakris, G. L., Horvath, A. R., Kirkman, M. S., et al. (2011). Guidelines and recommendations for laboratory anlysis in the diagnis and management of diabetes melitus. Diabetes Care, 34: 61-99.

Sherwood, L. (2012). Fisiologi Manusia. Edisi 6. Jakarta: Penerbit Buku Kedokteran EGC.

Smeltzer, S. O. \& Bare, B. G. (2012). Brunner \& Suddarth's texbook of medical surgical nursing. Philadelphia, Lippincott Williams \& Wilkins.

Surani, S., Brito, V., Surani, A., \& Ghamande, S. (2015). Effect of diabetes mellitus on sleep quality. World Journal of Diabetes, 6(6): 868. https://doi. org/10.4239/wjd.v6.i6.868

Tentero, I. N., Pangemanan, Damayanti, H. C., \& Polii, H. (2016). Hubungan 
diabetes melitus dengan kualitas tidur. EBiomedik, 4(2): 1-6. Retrieved from https://esources. perpusnas.go.id:2138/id/publications/64654/hubungan-diabetesmelitus-dengan-kualitas-tidur.

Wahyuningsih, Huriah, \& Sari. (2016). Hubungan kadar gula darah dengan insomnia pada penderita diabetes melitus. The Indonesian Journal of Health Science, 7(1): 54-63. 